\title{
The influence of environmental conditions on the morphological variability of phytoplankton in an oligo-mesotrophic Turkish lake
}

\author{
R. Akçaalan'*, M. Albay'1, C. Gürevin'1 , F. Çevik ${ }^{2}$ \\ ${ }^{1}$ Istanbul University Faculty of Fisheries Ordu Cad. No: 20034470 Laleli, Istanbul, Türkiye \\ ${ }^{2}$ Çukurova University, Faculty of Fisheries, Balcal1- Adana, Türkiye
}

\begin{abstract}
Phytoplankton dynamics and morphological plasticity were studied in an oligo-mesotrophic lake from late spring to early autumn in 2004 on a weekly to bi-weekly basis. This study aimed to evaluate the effect of environmental constraints on morphological plasticity and size structure of dominant species through the stratified period of the lake. While centric diatoms developed mainly in the epilimnion, Fragilaria crotonensis, Synedra sp. and Synedra acus were very well distributed through the whole water column, as was the cryptophyte Plagioselmis nannoplanctica. A filamentous cyanobacterium, Planktothrix rubescens, was stratified in the metalimnion throughout the sampling period, while Mougeotia sp. was entrained through the whole water column during the early autumn. Surface area / volume (S/V) ratios were calculated for the dominant species on each sampling date. The minimum S/V ratio was found with centric diatoms, while maximal values measured were for Synedra sp. and Asterionella formosa. The S/V ratio of the only dominant cryptophyte, Plagioselmis nannoplanctica was also high; variations were negatively correlated with $\mathrm{NO}_{3}-\mathrm{N}$ and $\mathrm{PO}_{4}-\mathrm{P}(-0.62$ and -0.61 , respectively) and positively correlated with euphotic depth $(\mathrm{r}=0.57)$ and temperature $(\mathrm{r}=0.82)$. On the other hand, the $\mathrm{S} / \mathrm{V}$ ratios of Fragilaria crotonensis and Cyclotella ocellata each showed strong negative correlation with silica concentrations ( -0.55 and -0.62 , respectively). It is concluded that allometric relationships showed significant differences among species according to depth and season.
\end{abstract}

Key words: phytoplankton, morphological plasticity, Lake Sapanca, environmental constraints, Surface-volume ratio

\section{Introduction}

Phytoplankton species show a wide range of diversity in their morphometric characters, even among closely related genera within the same phylogenetic division (Huszar \& Caraco 1998). This morphometric diversity may be the result of physiological adaptation to different environmental conditions (Margalef 1958). Thus, there has been considerable interest in classifying phytoplanktonic organisms into groups according to their morphometric characters, in order to understand the relationship between phytoplankton composition and environmental constraints. Reynolds (1997) has adapted Grime's (1973) scheme for terrestrial vegetation in 1973 to propose a framework for the morphological-functional description of phytoplankton composition, and in which organisms are partitioned in relation to three major strategies (R-, C- and Sstrategists), and which is very useful in explaining the phytoplankton dynamics in a given water body.

Phytoplankton are also a main component of pelagic

* Corresponding author: E-mail : akcaalan@istanbul.edu.tr ecosystems, since they are a primary source of energy in aquatic food webs (Hutchinson 1967) and because phytoplankton size and shape play an important role in determining its availability to particular grazing animals. Phytoplankters can alter their size and shape with changing physical conditions, such as light intensity, nutrient deficiency, mixing etc., as well as for the avoidance of predator pressure. Cell size also influences algal growth rates. Reynolds (1984) stated that cell size and shape influence on the metabolic activity that underpins cell growth. The general rule is that the smaller the cell, the greater is the surface/volume ratio and so is its relative rate of nutrient uptake. Therefore, nutrient availability in a lake may have a direct effect on phytoplankton composition and biomass and, together with changes in physical conditions, may lead to changes in species dominance from ones having higher surface/ volume ratios to ones with lower $\mathrm{S} / \mathrm{V}$ and vice versa.

Long-term studies on phytoplankton composition give a good idea about temporal changes that have occurred in the character of a lake. Lake Sapanca, a natural waterbody located $80 \mathrm{~km}$ east of Istanbul, does not have a long history of phytoplankton studies. Records 
on phytoplankton composition and abundance began only fifteen years ago. Nevertheless, water-quality studies, including chlorophyll- $a$ analyses, started a few years earlier than the phytoplankton records (Yigit et al. 1984). Therefore, it is difficult to talk about changes in phytoplankton over time. From the studies so far performed, it appears that the trophic state of the lake has changed little during these years, mainly the slight increase in nutrient concentrations in the lake that have raised the classification of the lake from oligotrophic to oligo-mesotrophic (Yigit et al. 1984, Tugrul \& Morkoc 1991, Albay et al. 2003). The lake has a metalimnetic Planktothrix rubescens population which has been monitored since 1997 (Albay et al. 2003); the presence of deep chlorophyll- $a$ maxima has been known since the 1980s. Moreover, Lake Sapanca is a reservoir, supplying drinking water to the nearby city with a population of 500,000 . It is moderately deep $(\max .55 \mathrm{~m}$, mean $26 \mathrm{~m}$ ); its surface area is $46.8 \mathrm{~km}^{2}$ and its volume is $\sim 1 \times 10^{9} \mathrm{~m}^{3}$ (DSI, 1989).

The aims of this study were to determine the composition and dynamics of phytoplankton in Lake Sapanca through the stratification period and to evaluate the effects of environmental constraints on morphological plasticity and size structure.

\section{Material and Methods}

The data refer to samples collected from the deepest part of the lake on a weekly and biweekly basis, between May and October 2004. Samples for chemical analyses and phytoplankton enumerations were collected at the surface and at depths of 5, 10, 15, 20, 30, 40 and $50 \mathrm{~m}$. Water samples for nutrient analysis $\left(\mathrm{NO}_{3^{-}}\right.$ $\mathrm{N}+\mathrm{NO}_{2}-\mathrm{N}, \mathrm{SRP}, \mathrm{TP}, \mathrm{SRSi}$ ) were kept cool and in the dark before being brought to the laboratory and analysed according to standard methods (APHA 1989). Temperature, dissolved oxygen, conductivity, $\mathrm{pH}$ were measured in situ using a multi-parameter probe (Radiometer, Pioneer 65). Euphotic zone ( $\left.\mathrm{Z}_{\mathrm{eu}}\right)$ was calculated as 2.7 times the Secchi disc transparency depth.

Phytoplankton subsamples $(100 \mathrm{ml})$ were fixed in Lugol's iodine solution and kept in glass bottles stored in the dark. Density was obtained by counting specimens until when 400 individuals of the most abundant species had been enumerated (Utermöhl 1958). The abundance of each species was based on cell counts, only filamentous species were considered as single units and abundance was expressed as individual per liter. Phytoplankton biovolumes and surface areas were estimated from original cell measurements, following the formulae of Hillebrand et al. (1999) and Sun \& Liu
(2003). Algal species representing $<5 \%$ of total biomass were not included in Surface area/Volume (S/V)ratio calculations. Picoplankton was not included in the calculation of total phytoplankton biomass. Species were also categorized into four groups according to their Greatest Axial Linear Dimension (GALD): $<25 \mu \mathrm{m}$ (Group 1), 25-75 $\mu \mathrm{m}$ (Group 2), 75-150 $\mu \mathrm{m}$ (Group 3) and $>150 \mu \mathrm{m}$ (Group 4). To determine whether any differences in cell $\mathrm{S} / \mathrm{V}$ ratio and biomass were associated with increasing depth, the water column was characterised by reference to three separate layers: 0-10 m (L1), 15-20 m (L2) and 30-50 m (L3).

Cluster analysis was undertaken using the completelinkage method, applied to distance matrices obtained from biomass data, transformed to their double square roots. Ordination of the data followed the Statistica software package (Statsoft Inc. 2001). The relationships between cell surface area/volume ratio and phytoplankton biomass with environmental variables were explored by Canonical Correspondence Analysis (CCA) using CANOCO 4.5 software (ter Braak \& Smilauer 2002). Before computation, double square root transformation of biomass data was made to reduce weighting by the most abundant species.

\section{Results}

\section{Physical and chemical environment}

Lake Sapanca is a warm monomictic lake (min $7.2{ }^{\circ} \mathrm{C}$ at $50 \mathrm{~m}$ depth and $\max 27.5^{\circ} \mathrm{C}$ at the surface). Thermocline formation generally starts in May and ends with the beginning of the circulation period in November. In previous years, a distinct thermocline was generally present in the lake throughout the summer but, in August 2004, stratification was exceptionally disrupted, resulting in unusually high temperatures (up to $25^{\circ} \mathrm{C}$ ) being measured in the deepest part of the lake $(50 \mathrm{~m})$. By the next sampling, water temperature had decreased to $18{ }^{\circ} \mathrm{C}$ in the epilimnion and $16^{\circ} \mathrm{C}$ in the hypolimnion (Figure 1). The most likely cause for such unusual behaviour is seismic activity, as the lake straddles one branch of North Anatolian Fault System (Neugebauer et al., 1997) and along which a large earthquake occurred in 1999. The lake water is slightly alkaline and the $\mathrm{pH}$ ranged between 7 and 8.9 during the sampling period. Nutrient concentrations remained generally low, with mean values for $\mathrm{N}_{-} \mathrm{NO}_{3}+\mathrm{N}-\mathrm{NO}_{2}$ of $45 \mu \mathrm{g} \mathrm{l}^{-1}$, for TP of $13 \mu \mathrm{g} \mathrm{l}^{-1}$ and $984 \mu \mathrm{g} \mathrm{l}^{-1}$ for SRSi. SRP concentrations were always very low and below detection limits on many sampling dates. 


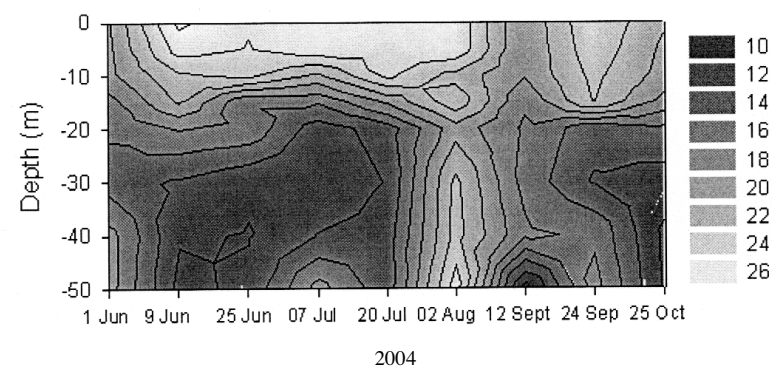

Fig. 1. Depth-time diagrams of water temperature in the sampling period

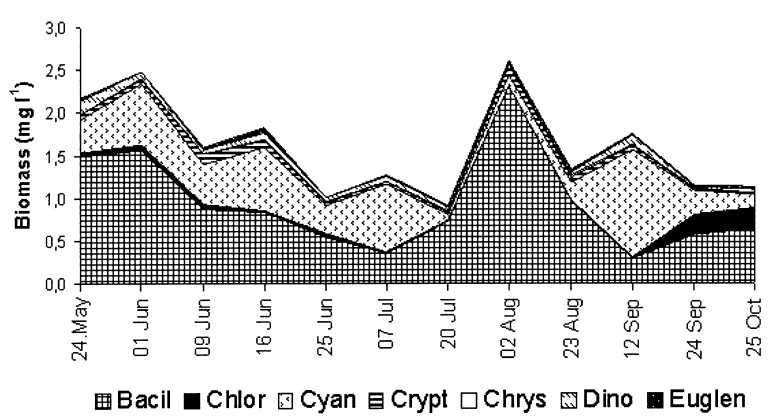

Fig. 2. Seasonal successions of mean biomass of the main phytoplankton groups in the whole water column.

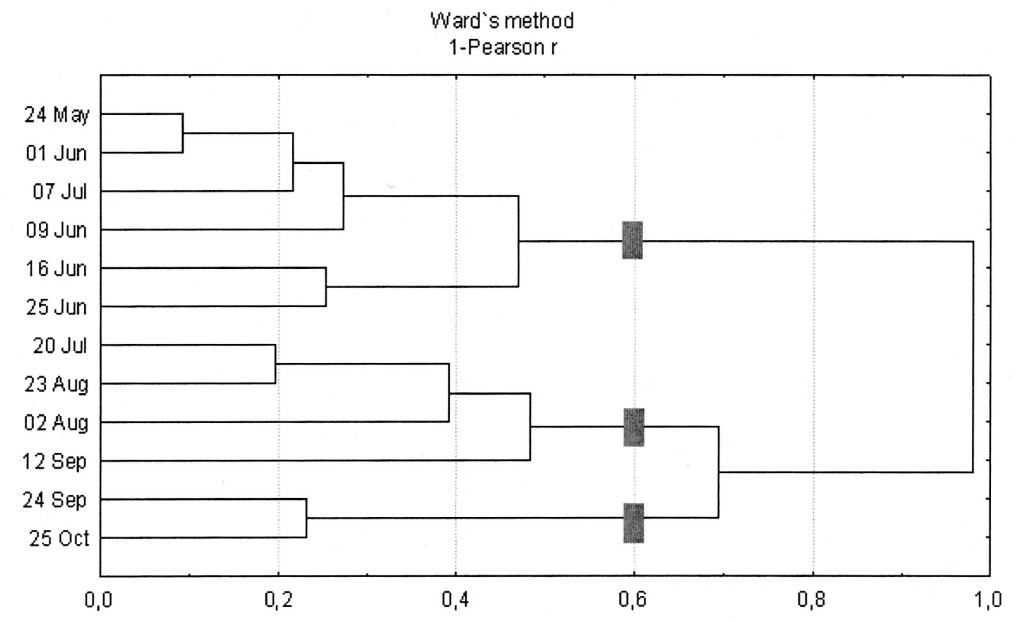

Fig. 3. Ordination of the samples in seasonal clusters.

\section{Phytoplankton succession}

Variations in the total biomass values showed two major peaks (at the end of May and at the beginning of August), exceeding $2000 \mu \mathrm{g} \mathrm{l}^{-1}$ on either occasion. The mean biomass during the sampling period was found to be $1607 \mu \mathrm{g} \mathrm{l}^{-1}$. Bacillariophyta were the dominant algal group throughout the whole season. Cyanobacteria were represented by filamentous species, mainly Planktothrix rubescens, which formed a metalimnetic population. Cryptophyta, represented principally by Plagioselmis nannoplanctica, were present in high numbers (but low biomass) throughout the sampling period. Other groups contributed only slightly to the total algal biomass present. Figure 2 shows the seasonal successions of mean biomass of the main algal groups in the whole water column.
The results of cluster analysis are reported in Figure 3. In the tree diagram obtained from biomass data, the higher hierarchical level indicates a separation between the three main groups with a dissimilarity level of 0.5 . These groups divide the sampling period as early summer, summer and early autumn. On the basis of its large-sized units, Planktothrix rubescens was the dominant species in early summer, while Synedra spp. and Fragilaria crotonensis were sub-dominant. In summer, Fragilaria crotonensis took over the dominance of the assemblage when its biomass constituted $80 \%$ of total biomass. In the same period, Plagioselmis nannoplanctica reached relatively high numbers but its contribution to total biomass remained low, as a consequence of its small unit size. In early autumn, three larger-sized species, Planktothrix rubescens, Fragilaria crotonensis and Mougeotia sp., co-dominated. 
On the basis of the GALD-division, the discrimination of seasonal groupings was very similar to the separation of the biomass data. Group $4(>150 \mu \mathrm{m})$ was dominant in early summer samples and group 2 and 3 were co-dominant groups. In summer samples, Group 3 became dominant, as a result of the increase of Fragilaria crotonensis biomass. Although the contribution of Group 2 was maintained into the autumn, Group 4 also became important and constituted $30 \%$ of total biomass. The contribution of Group 1 to total biomass was always a low percentage (Figure 4).

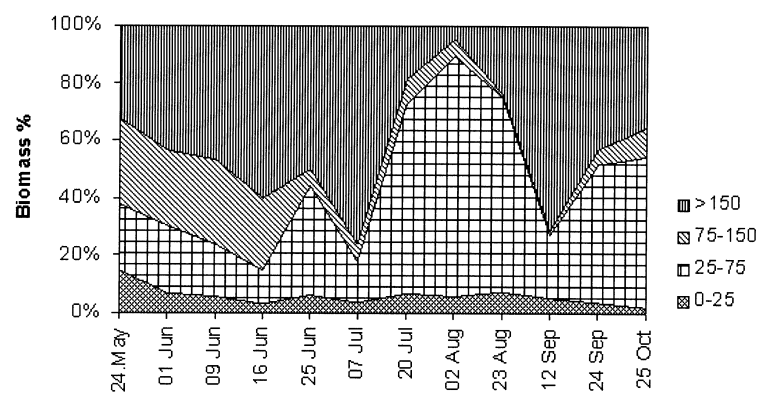

Fig. 4. Seasonal changes of the phytoplankton groups according to their GALD values.

Taking the categories distinguished by S/V ratios, species with ratios of between 0.7-1 were dominant at the beginning of the stratification period, with only a small contribution of species having $\mathrm{S} / \mathrm{V}$ ratios $>1$. During summer and early autumn, the second group $(\mathrm{S} / \mathrm{V}$ ratio: $0.7-1$ ) reached high biomass and constituted $90 \%$ and $98 \%$ of the total biomass, respectively. The smallest group $(<0.7)$ was never exceed $10 \%$ of total biomass in the study period. Table 1 shows mean, minimum and maximum $\mathrm{S} / \mathrm{V}$ ratios of dominant species.

Table1. Number of measurements, mean, minimum, maximum S/V values and Standard deviation of dominant species of Lake Sapanca.

\begin{tabular}{lccccc}
\hline & $\begin{array}{c}\text { No of } \\
\text { measurement }\end{array}$ & $\begin{array}{c}\text { Mean } \\
\text { S/V }\end{array}$ & $\begin{array}{c}\text { Min. } \\
\text { S/V }\end{array}$ & $\begin{array}{c}\text { Max. } \\
\text { S/V }\end{array}$ & $\begin{array}{c}\text { Standard } \\
\text { Deviation }\end{array}$ \\
\hline Stephanodiscus sp. & 39 & 0.62 & 0.55 & 0.71 & 0.03 \\
C. ocellata & 67 & 0.67 & 0.56 & 0.82 & 0.06 \\
P. rubescens & 50 & 0.81 & 0.8 & 0.83 & 0.006 \\
F. crotonensis & 73 & 0.88 & 0.82 & 1.12 & 0.08 \\
Mougeotia sp. & 35 & 0.95 & 0.8 & 1.29 & 0.15 \\
S. acus & 77 & 1.21 & 0.99 & 1.55 & 0.1 \\
P. nannoplanctica & 79 & 1.36 & 1.02 & 2.05 & 0.16 \\
A. formosa & 47 & 1.64 & 1.37 & 2.25 & 0.099 \\
Synedra sp. & 85 & 1.7 & 1.54 & 2.45 & 0.18 \\
\hline
\end{tabular}

\section{Depth distribution of phytoplankton}

With reference to the horizontal layers chosen, the main species in the upper layer (L1) were Synedra spp. and Fragilaria crotonensis in the early summer, with minor contributions of Asterionella formosa and $C y$ clotella-Stephanodiscus group. In summer, Fragilaria crotonensis became the most important species contributing with a $90 \%$ to total biomass. Synedra sp and $C y$ clotella sp. constituted the rest of the total biomass. During the autumn, Mougeotia sp. became the second most important alga in this layer, after Fragilaria crotonensis. Nutrients showed no relationship with the biomass of dominant summer species, Fragilaria crotonensis and Planktothtix rubescens; on the other hand, Synedra abundance showed a weak relationship with TP and SRP (Figure 5a). Similar results were also obtained for the $\mathrm{S} / \mathrm{V}$ ratio of these species. The $\mathrm{S} / \mathrm{V}$ ratio of Asterionella formosa, however, was dependent on SRSi and Dissolved Oxygen (Figure 5b).

In the second layer (L2: 15-20 m, coinciding with the metalimnion), the dominant species was Planktothrix rubescens, having migrated down to the metalimnion in early summer. In the beginning of summer, phytoplankton became very diverse, following the disruption of the thermocline. Synedra spp, Planktothrix rubescens, Stephanodiscus sp. and Fragilaria crotonensis contributed substantially to total biomass and in approximately similar proportions. However, Planktothrix rubescens again became dominant in this layer towards the end of summer, with Fragilaria crotonensis subdominant. In early autumn, the Planktothrix rubescens population decreased and Mougeotia sp. took over the dominance, with a contribution from Fragilaria crotonensis. In this layer, Fragilaria crotonensis biomass was mainly related to temperature and $\mathrm{pH}$, and other colony-forming pennate diatom, Asterionella formosa, which had a low biomass throughout the sampling period, related to SRSi and $\mathrm{NO}_{3}+\mathrm{NO}_{2}$. While Plagioselmis nannoplanctica and Cyclotella ocellata were controlled by light availability and also temperature, Stephanodiscus sp. was controlled by SRP (Figure 5c). On a S/V ratio basis, Synedra sp., Plagioselmis nannoplanctica and Cyclotella ocellata were mainly dependent on temperature and also conductivity had an effect on these species (Figure 5d).

In the bottom layer (L3), species dominance showed a similar pattern to that in L2. Their major group consisted of Planktothrix rubescens and the colonyforming (Fragilaria crotonensis) or the needle-shaped, unicellular (Synedra spp.) pennate diatoms. In early autumn, Mougeotia sp contributed a higher proportion of the total biomass. Planktothrix rubescens showed a 

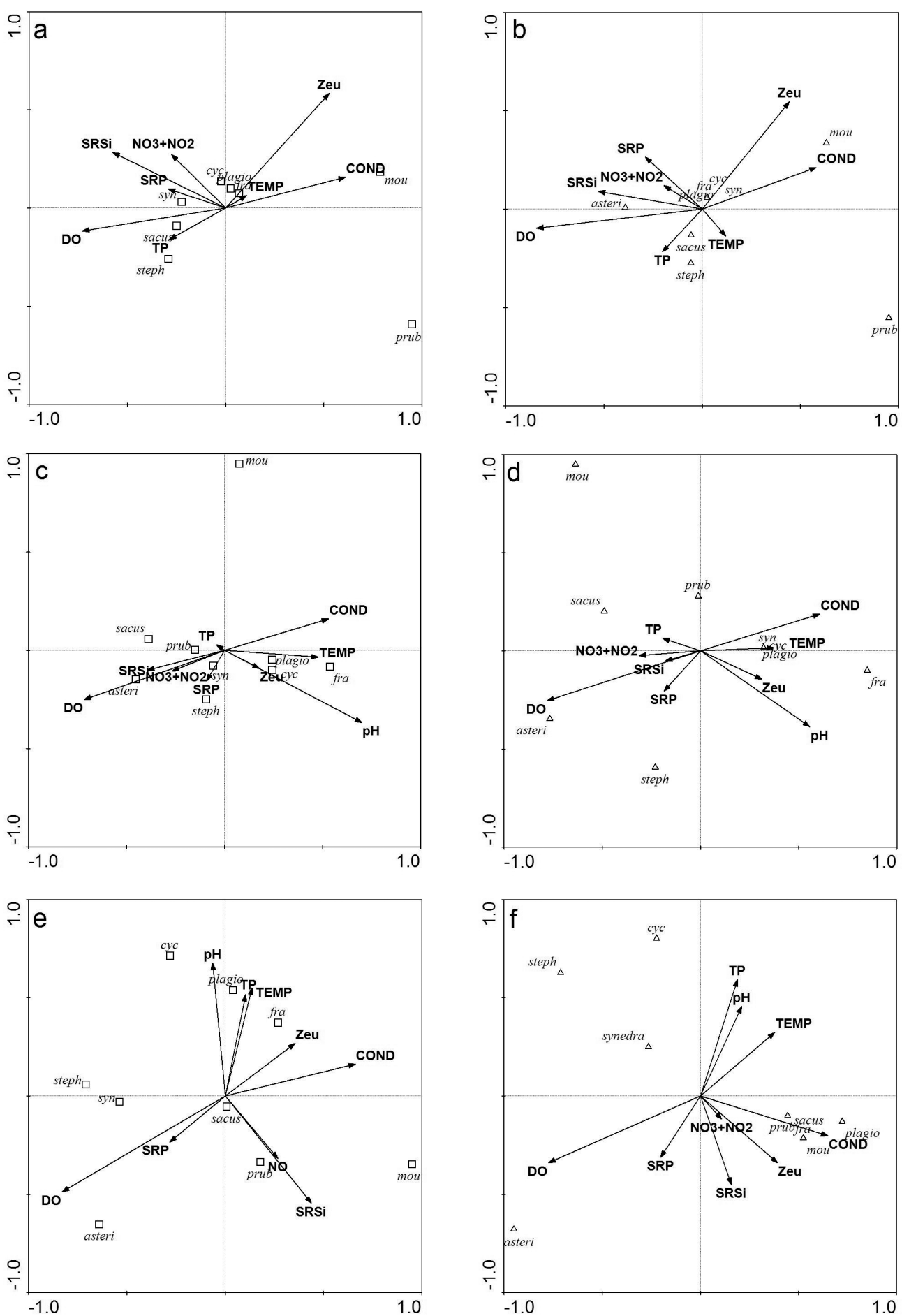

Fig. 5. Biplot of biomass values (a: in L1, c: in L2, e: L3) and S/V ratio (b: in L1, d: in L2, f: in L3) with environmental variables at three depth interval. Arrows represented environmental variables and species abbreviations are: asteri: Asterionella formosa, Cyc: Cyclotella ocellata, steph: Stephanodiscus sp. Asterionella formosa, fra: Fragilaria crotonensis, sacus: Synedra acus, synedra: Synedra sp., plagio: Plagioselmis nannoplanctonica, mou: Mougeotia sp., prub: P. rubescens 
significant relationship with $\mathrm{NO}_{3}+\mathrm{NO}_{2}$, whereas, light availability, temperature and TP affected Fragilaria crotonensis biomass (Figure $5 \mathrm{e}$ ). Conductivity and light availability showed a major effect on the S/V ratio of elongated species, like Fragilaria crotonensis, Planktothrix rubescens, Mougeotia sp., Synedra acus, and also one small species (Plagioselmis nannoplanctonica) with a higher $\mathrm{S} / \mathrm{V}$ ratio (Figure $5 \mathrm{f}$ ).

\section{Discussion}

Diatoms were the most important component of the phytoplankton assemblage during the stratification period in Lake Sapanca. According to nutrient concentrations, Lake Sapanca can be classified as oligo-mesotrophic, in which phosphorus and, from time to time, nitrogen may act as limiting factors for algal growth (Tufekci 1999). Under these conditions, dominant species are selected among the stronger competitors for phosphorus. During the study period, diatom biomass was dominated by Fragilaria crotonensis, Asterionella formosa and Synedra sp. These three species are wellknown to be good competitors in natural phytoplankton communities under phosphorus limitation (Sommer 1985). Although they can grow under phosphorusdeficient conditions, another nutrient, silicon, became the most important factor, since these species, especially Synedra sp., cannot thrive under low Si concentrations (Kilham et al. 1986). The Synedra population decreased rapidly one month after stratification started, although $\mathrm{Si}$ concentration had not fallen to especially low levels. However, other nutrients (SRP and $\mathrm{NO}_{3}+\mathrm{NO}_{2}$ ) did show sharp falls in epilimnetic concentration and which would not normally be replenished from reserves isolated in the hypolimnion. Under these conditions, Fragilaria crotonensis took the place of Synedra sp. and formed a dense population in late summer and autumn. In August, especially, Fragilaria crotonensis reached high numbers and $90 \%$ of total biomass. Normally, Lake Sapanca has a special segregation which forms a barrier between nutrient-rich hypolimnia and nutrient-poor epilimnia in summer months. Because of the evident disruption of the typical segregation of a nutrient-poor epilimnion from a nutrientrich hypolimnion, attributed to seismic activity experienced in 2004, diatoms would have been able to travel more deeply and nutrients in the hypolimnetic water would have been entrained into the upper, productive layers. Under these conditions, Fragilaria crotonensis outcompeted Planktothriz rubescens in terms of biomass through the whole water column. Fragilaria crotonensis is known to reach high biomass in the lakes with differing trophic state, from oligo-mesotrophic to eutrophic (Salmaso 2002, Albay \& Akcaalan 2003).
Planktothrix rubescens established a metalimnetic population between early summer and autumn. Its contribution to total biomass was relatively high $(40 \%)$. Planktothrix rubescens concentrated in the thermocline where nutrient concentrations and physical conditions do not fluctuate greatly with time; being a buoyant, self-regulating species, $P$. rubescens is able to adjust its position to gain the optimal blend of growth conditions available (e.g. low light and available nutrients coming from the hypolimnion). Thus, its morphological plasticity is not closely related to changing nutrient conditions or physical disturbance (Morabito et al. 2007). Moreover, large algae often attenuate their shape to preserve a favourable ratio of surface area to volume (Reynolds 1984).

Plagioselmis nannoplanctica was the most important representative of the Cryptophyta, accounting for $30 \%$ of total density in late summer. As a group, cryptophytes are ubiquitous species and their presence is not related to nutrient concentrations (Reynolds, 1984, Dokulil, 1988), the main factors affecting their seasonality are temperature and light intensity (Barone \& Naselli-Flores 2003). This was confirmed in the present study by the significant correlations highlighted in the CCA ordination between Plagioselmis nannoplanctica and temperature.

Cell size has a strong influence on cell physiology and it is known that smaller organisms are metabolically more active as many metabolic processes are scaled with the size of the cells (Reynolds 1997). The general agreement is that increasing cell size generally results in decreased growth rates (Tang 1995, Reynolds 1984). Along with size, the surface area/volume ratio of a cell is among the main determinants of its potential physiological performance. A high cell surface/volume ratio enables the organism to exchange materials across and between its boundaries more efficiently (Reynolds 1997). Especially under low nutrient conditions, species with a high surface-to-volume ratio are able to take advantage of this situation. However, high $\mathrm{S} / \mathrm{V}$ ratios are not only dependent on cell size but also on cell shape (Teubner 2003). As can be seen in our results, dominant diatoms in the lake were mainly composed of needle-shaped ones with the high $\mathrm{S} / \mathrm{V}$ ratio characterising $\mathrm{R}$-strategists, and the most abundant Cyanobacteria (Planktothrix rubescens) are filamentous.

By relative biomass, the prominent species encountered in the present study included Fragilaria crotonensis, Planktothrix rubescens, Asterionella formosa and Synedra sp. These last species belong to different 
GALD classes and show a minimum length of $60 \mathrm{~mm}$. Three further species, Cyclotella ocellata, Stephanodiscus sp. and Plagioselmis nannoplanctica belong to GALD group $1(<25 \mu \mathrm{m})$ together failed to account for more than $10 \%$ of total biomass during the sampling period. Several models of phytoplankton growth rate have been used to predict whether large and small cells should predominate under different environmental conditions (Parsons \& Takahashi 1973, Kagami \& Urabe 2001). There is general agreement that smaller cells have faster growth rates (Reynolds 1984, Tang 1995). However, Kagami \& Urabe (2001) found that cell size not always has a negative correlation with growth rate in their in situ experiment and suggested that allometric relationships between growth rate and cell size do not necessarily hold for algal communities in given natural habitats. There are many factors, including nutrient supply, light intensity, water stability, temperature or grazing, that affect algal growth rate and the succession of phytoplankton communities from large species to small ones or vice versa. However, it is difficult to separate any one single factor to account for such changes of phytoplankton composition in natural habitats.

To compare the density data with biomass values according to size distribution, the contribution of the smallest group (GALD $<25 \mu \mathrm{m}$ ) increased to $40 \%$ in late summer with the dominance of Plagioselmis nannoplanctica. Bergquist et al. (1985) showed that particle size distributions are closely coupled to grazing dynamics in plankton communities. Zooplankton composition in Lake Sapanca mainly comprised small rotifers and the contribution of Cladocera and Copepods to total density were negligible. Also, zooplankton density in July and August is very low (Okgerman, Pers. Comm.). This situation may have permitted the increase in the population of Plagioselmis nannoplanctonica.

In conclusion, the main driving factors for phytoplankton in Lake Sapanca are nutrient concentrations. At the beginning of the stratification period, nutrient concentrations were sufficient to support algal species which depend upon higher nutrient concentrations. However, the community changed with the decrease of phosphorus and nitrogen in the epilimnion and species which are less dependent upon the ready availability of nutrients, especially phosphorus, became dominant. Moreover, according to $\mathrm{S} / \mathrm{V}$ ratios, the ordination of species indicates a niche separation among species, Asterionella formosa, Stephanodiscus sp., which were mainly related to weak stratification characterized by high dissolved oxygen and nutrient availability and
Fragilaria crotonensis which was mostly controlled by high temperature and light availability. Also, the disruption of the thermocline in August promoted a major change in the dominant species, from stratified Planktothrix rubescens to large diatoms, especially Fragilaria crotonensis, through the whole water column.

\section{Acknowledgements}

We wish to thank Mr. Adnan Sümer for their assistance in the field. We are grateful to Dr. Guiseppe Morabito and Dr. Luigi Naselli-Flores for improving an earlier version of this work and to Dr. Colin Reynolds for the correction of English of the manuscript. This study was partly supported by TUBITAK (Project number: 103Y131).

\section{References}

Albay M. \& Akcaalan R. 2003. - Factors influencing the phytoplankton steady state assemblages in a drinking-water reservoir (Ömerli reservoir, Istanbul). Hydrobiologia, 502, 85-95.

Albay M., Akcaalan R., Tufekci H., Metcalf J.S., Beattie K.A. \& Codd G.A. 2003. - Depth profiles of cyanobacterial hepatotoxins (microcystins) in three Turkish freshwater lakes. Hydrobiologia, 505, 89-95.

APHA, AWWA \& WEF 1989. - Standart methods for the examination of water and wastewater. 17th Edition, American Public Health Association, Washington.

Barone R. \& Naselli-Flores L. 2003. - Distribution and seasonal dynamics of Cryptomonads in Sicilian water bodies. Hydrobiologia, 502, 325-329.

Bergquist A.M., Carpenter S.R. \& Latino J.C. 1985. - Shifts in phytolankton size structure and community composition during grazing by contrasting zooplankton assemblages. Limnol. Oceanogr., 30, 1037-1045.

Dokulil M. 1988. - Seasonal and spatial distribution of cryptophycean species in the deep, stratifying, alpine lake Mondsee and their role in the food web. Hydrobiologia, 161, 185-201.

DSI 1989. - Seminar of water quality observations, control and case studies: the Sapanca lake and its drainage area, DSI Publication, 228-330. (in Turkish).

Grime J.P. 1973. - Competitive exclusion in herbaceous vegetation, Nature 242, 344-347

Hillebrand H., Dürselen C.D., Kirschtel D., Pollinger U. \& Zohary T. 1999. - Biovolume calculation for pelagic and benthic microalgae. J. Phycol., 35, 403-424.

Huszar V.L.D.M. \& Caraco N.F. 1998. - The relationship between phytoplankton composition and physical-chemical variables: a comparison of taxonomic and morphological-functional descriptors in six temperate lakes. Freshwat. Biol., 40, 679-696.

Hutchinson G.H. 1967. - A treatise on limnology, Vol. II, Introduction to lake biology and the limnoplankton. John Wiley \& Sons, New York.

Kagami M.\& Urabe J., 2001. - phytoplankton growth rate as a function of cell size: an experimental test in Lake Biwa. Limnology, 2, 111-117.

Kilham P., Kilham S.S. \& Hecky R.E. 1986. - Hypothesized resource relationships among Afrikan planktonic diatoms. Limnol. Oceanogr., 31, 1169-1181.

Margalef R. 1958. - Temporal succession and spatial heterogeneity in phytoplankton. In Buzzati-Treverso, A.A. (eds.), Perspectives in Marine Biology. University of California Press, Berkeley, 323-349. 
Morabito G., Oggioni A., Caravati E. \& Panzani P. - 2007. Seasonal morphological plasticity of phytoplankton in Lago Magiiore (N. Italy). Hydrobiologia, 578, 47-57.

Neugebauer J., Löffler M., Berckhemer H. \& Yatman A. 1997. Seismic observations at an overstep of the western North Anatolian Fault (Abant-Sapanca region, Turkey). Geologische Rundschau, 86,93-102.

Parsons T.R.\& Takahashi M. 1973. - Environmental control of phytoplankton cell size. Limnol. Oceanogr., 18, 511-515.

Reynolds C.S. 1984. - The ecology of freshwater phytoplankton. Cambridge University Press, Cambridge. 384 pp.

Reynolds C.S. - 1997. Vegetation processes in the pelagic: a model for ecosystem theory. Ecology Institute, Oldendorf, $371 \mathrm{pp}$.

Salmaso N. 2002. - Ecological patterns of phytoplankton assemblages in lake Garda: Seasonal, spatial and historical features. J.l Limnol., 61, 95-115.

Sommer U. 1985. - Comparison between steady state and nonsteady state competition: Experiments with natural phytoplankton. Limnol. Oceanogr., 30, 335-346.

Sun J.\& Liu D. 2003. - Geometric models for calculating cell biovolume and surface area for phytoplankton. J. Plankton Res., 25, 1331-1346.
Tang E.P. 1995. - The allometry of algal growth rates. Journal of Plankton Research, 17, 1325-1335.

ter Braak C.J.F. \& Smilauer P. 2002. - CANOCO referans manual and CanoDraw for Windows user's guide: Software for Canonical Community Ordination (version 4.5). Microcomputer Power, Ithaca, $500 \mathrm{pp}$.

Teubner K. 2003. - Phytoplankton, pelagic community and nutrients in a deep oligotrophic alpine lake: ratios as sensitive indicators of the use of P-resources (DRP:DOP:PP and TN:TP:SRSi). Water Res., 37, 1583-1592.

Tufekci H. 1999. - Distribution and seasonal changes of phytoplankton biomass and primary productivity in lake Sapanca. $P h D$ thesis, 107 pp. (In Turkish).

Tugrul S. \& Morkoç E. 1991. - Determination of limnological characteristics of the Sapanca Lake. Doga-Turkish J. Engine. Environ. Sci., 15, 265-282.

Utermöhl H. 1958. - Vervollkommung der quantitativen Phytoplankton-methodik. Mitt. Int. Ver. Theor. Angewan. Limnol.,9, -38.

Yigit V., Müftügil N., Ozalp N., Ergen C., Arvas H. \& Yolcular H. 1984. - An investigation on the water quality and trophic state of Lake Sapanca. Technical Report. TUBITAK-MBEAE. 